\title{
La proscription et les origines de l'Internationale. Présentation
}

Réédition de l'article paru dans 1848 - Revue des révolutions contemporaines, n 189, décembre 1951, p. 97

\section{(2) OpenEdition}

Journals

Édition électronique

URL : http://journals.openedition.org/rh19/297

DOI : 10.4000/rh19.297

ISSN : $1777-5329$

Éditeur

La Société de 1848

Édition imprimée

Date de publication : 1 juin 2001

ISSN : 1265-1354

Référence électronique

"La proscription et les origines de I'Internationale. Présentation », Revue d'histoire du XIXe siècle [En

ligne], 22 | 2001, mis en ligne le 13 octobre 2002, consulté le 02 mai 2019. URL : http://

journals.openedition.org/rh19/297; DOI : 10.4000/rh19.297

Ce document a été généré automatiquement le 2 mai 2019.

Tous droits réservés 


\section{La proscription et les origines de l'Internationale. Présentation}

Réédition de l'article paru dans 1848 - Revue des révolutions contemporaines, $\mathrm{n}^{\circ} 189$, décembre 1951, p. 97

Le coup d'État mérite d'être examiné dans ses répercussions sur l'avenir du mouvement ouvrier international. En déconsidérant la Montagne, il favorisait, en France, comme dans la proscription à l'étranger, les éléments les plus avancés, les blanquistes. Surtout, par la résistance qu'il provoqua et la répression qui en résulta, il reproduisait l'atmosphère de terreur bourgeoise qui avait répondu à l'insurrection de juin et il faisait de LouisNapoléon un gendarme au service de l'Ordre social. En regard de son incidence sur la proscription, dont le début remontait à Juin 1848, le coup d'État non seulement en accroissait numériquement l'importance, mais poussait à ses dernières conséquences la situation issue des événements de juin. Aussi devait-il inciter à une réorganisation générale, sur une base ouvrière et internationaliste, du mouvement révolutionnaire qui, en France, venait de se révéler incapable d'entraîner les masses.

Dans le cadre de ces considérations générales, MM. R. Gossez et N. Plotkin se sont intéressés, le premier à un " précédent " de l'Internationale, en se fondant principalement sur le journal des proscrits à Jersey, l'Homme, le second aux alliances des Blanquistes dans la proscription d'après la correspondance inédite de Blanqui. Si l'amalgame de leurs articles publiés ci-après n'a pu se faire, l'un étant composé pour l'impression quand l'autre a été communiqué, ils représentent, tels quels, une contribution à l'étude des origines de l'Internationale. 